\title{
The Performance Analysis of The Community Economic Institutions (LEM) in Increasing Farmers' Income of Cocoa Farming System
}

\author{
Rusdin ${ }^{1}$, Dahya, Agussalim ${ }^{1}$, Sarjoni ${ }^{1}$ and Julian Witjaksono ${ }^{1, *}$ \\ ${ }^{1}$ The Assessment Institute for Agricultural technology of Southeast Sulawesi. Kendari. 93114. \\ Indonesia
}

\begin{abstract}
Cocoa is a predominant crop estate commodity produced in Southeast Sulawesi. The main constrain increasing cocoa productivity regarding the non-technical factor is developing cocoa community. The government has launched Cocoa Community Institution (LEM) to overcome lack of community development in a cocoa farming system. This study aims to identify institutions related to the community development based on cocoa commodity and to analyze the performance of LEM. This study was conducted in two Sub-Districts (Lambuya and Besulutu) of Konawe district in Southeast Sulawesi province. Participatory method was implemented to get the primary data through an open interview based on the performance indicators of LEM Sejahtera. The number of respondents was 30 farmers chosen by simple random sampling. The Cocoa Community Institution was the main purpose of this study focusing on its performance of LEM Sejahtera in enhancing smallholders' income. The results of this study indicated that LEM Sejahtera in Besulutu had contributed significantly to supply input and lend money to help poor resource farmers based on the community development program.
\end{abstract}

\section{Introduction}

Direction, policy, and government programs that will be pursued in the development of cocoa agribusiness include long-term policies in 2025 and medium-term policies (20102010), which include: a) Policy of cocoa productivity and quality improvement; b) Policy to increase the value and income of cocoa farmers; and c) Policy on providing sources of financing from both banking and non-bank institutions, while the medium-term includes: a) productivity improvement policy; b) Farmer empowerment policy; c) Institutional structuring policy; (d) Results processing and marketing policy, and (e) Infrastructure strengthening policy [1]. This policy is intended to encourage cocoa exports to be no longer as raw materials (seeds), but as processed products. Therefore, the country will receive added value of the cocoa commodity and increase good quality of cocoa beans produced mostly by smallholder farmers [2].

\footnotetext{
*Corresponding author: julian_witjaksono@yahoo.com
} 
Cocoa is a leading commodity as the primary source of livelihood in Southeast Sulawesi. Cocoa development area in Southeast Sulawesi successively has planted in North Kolaka district 79,301 ha, Kolaka District 29,588 ha, South Konawe District 20,316 ha, Konawe District 14,900 ha and Bombana District 10,533 ha, while other districts/cities have development areas below 10,000 ha [3]. The existing conditions faced by cocoa farmers in Southeast Sulawesi are the attack of organism plant disruptors such as Cocoa Fruit Fryer and phytopthora palmivora mushrooms that cause fruit rot reducing production by $26-56$ percent [4]. In addition to technical factors, the key to successfully building smallholder cocoa plantation is also determined by institutional farming. The institutional existence of farmers will encourage the provision of input such as fertilizer and pesticide, cultivation, post-harvest, agroindustry, marketing, banking, and partnership networking [5].

Through the BAHTERAMAS Program, the Government of Southeast Sulawesi strengthened the institutions of farmers in the countryside through prosperous community economic institutions (LEM) to improve the existing peasant institutions. LEM Sejahtera is a village economic institution formed from, by, and for the local community by gathering self-help powers to use the potential resources available to improve the welfare of all its members [6].

Over time, the name of LEM Sejahtera, which is popular in Southeast Sulawesi is uniformed into the Community Economic Institute abbreviated "LEM" which is valid throughout Indonesia starting in 2017.The institutional role of farmers in improving the cocoa farming system is crucial. Input support from production facilities, labour, and market is very influential in the course of its farming. According to [7], the existence and development of agribusiness cannot be released from the institutional aspect (institutional agribusiness). The institution contains the meaning of institutions and organizations that include roles and attitudes in the community's norms and values.

LEM is the accessibility of the community (farmers) to the institutional existence of agribusiness and the rules of the game in the institution of agribusiness itself. The agribusiness institutions include production facilities in the form of agricultural inputs (including labour), production technology and agricultural implementation (including mechanization), harvesting, post-harvest, processing, financing, farming group organization, and advising [8]. This research aimed to identify institutions related to the development of cocoa, and to know the institutional performance of cocoa farmers. It is hoped that this research will be the material of policymakers' recommendations for broader and sustainable institutional development and effective and efficient to improve people's well-being.

\section{Methodology}

\subsection{Research Method}

This study was conducted from January to December 2019 in Konawe Regency because Konawe Regency has LEM, LEM Sejahtera namely based on cocoa commodity. In addition, it is one of the cocoa development centres in Southeast Sulawesi. This research activity included institutional identification related to the development of the cocoa community, measurement of the institutional performance of farmers (LEM Sejahtera) in supporting the cocoa farming system by using participatory methods. 


\subsection{Data Collection}

To determine the institutional performance of farmers, we conducted an open interview with members of farmers group or the members of LEM Sejahtera in Besulutu Sub District and Lambuya Sub District. Five villages of LEM Sejahtera were chosen deliberately (purposive sampling), while farmers respondents were chosen randomly (simple random sampling) as many as 30 farmers members of LEM Sejahtera and non-members of LEM Sejahtera.

\subsection{Data Analysis}

Data collected were analysed to measure the institutional performance of LEM Sejahtera by using the assessment score technique shown in the following table.

Table 1. The Performance Indicators of LEM Sejahtera

\begin{tabular}{|c|l|l|}
\hline $\begin{array}{c}\text { Lem Sejahtera } \\
\text { Performance } \\
\text { assessment } \\
\text { category }\end{array}$ & Qualification & Performance Indicators \\
\hline A & Good & $\begin{array}{l}\text { LEM Sejahtera Organization already has an excellent } \\
\text { capacity to maintain its existence towards self-reliance } \\
\text { and sustainability. }\end{array}$ \\
\hline B & Enough & $\begin{array}{l}\text { LEM Sejahtera organization already has innovative } \\
\text { ideas and move to look forward }\end{array}$ \\
\hline C & Not good & $\begin{array}{l}\text { LEM Sejahtera organization already has organizational } \\
\text { goals, plans, and devices which are strong enough to } \\
\text { grow up. However, it is still essential to improve its } \\
\text { performance to achieve higher development. }\end{array}$ \\
\hline
\end{tabular}

\section{Results and Discussion}

\subsection{Characteristics of Cocoa Farmers}

The success of farmers in managing their business in addition to being determined by the bio-physical factors of the land, the availability of inputs and the price of inputs is also determined by the socio-economic conditions of the farmer itself [9]. Several social factors that influenced the successful of cocoa farming system were age, experience of farming, formal education, land area, availability of family labour, and capital capability. These socio-economic factors can influence farmers' considerations in decision-making to implement recommended technology [10]. The socio economic characteristics of the cocoa farming system in both locations are presented in Table 2.

Table 2. Cocoa Farmers Profile in Lambuya and Besulutu, Konawe Regency, 2019

\begin{tabular}{|c|l|c|c|c|}
\hline No. & \multicolumn{1}{|c|}{ Justification } & Lowest & Highest & Average \\
\hline 1 & Age (years old) & 23 & 66 & 44 \\
\hline 2 & $\begin{array}{l}\text { Terms of formal education } \\
\text { (years) }\end{array}$ & 3 & 12 & 7 \\
\hline 3 & $\begin{array}{l}\text { Number of family members } \\
\text { (person) }\end{array}$ & 2 & 7 & 3 \\
\hline 4 & Land Cultivated & 1 & 4 & 2 \\
\hline 5 & Years experienced & 5 & 30 & 17 \\
\hline
\end{tabular}

Source: Primary data collected 
Table 2 showed that the average age of farmers at the assessment site was in productive age, which means that they can work well, with an average formal education period of 7 years (junior high school) [11]. Similarly, based on the potential availability of family labour, it still helps to carry out cocoa farming activities from land ownership due to the average cocoa farming experience [12]. Meanwhile, based on the experience of farming, the average farmer of this study had experience and had learnt from the Field School of cocoa cultivation.

\subsection{LEM institutional performance}

To develop cocoa community, several institutions related to the cocoa farming system play important roles in the success and sustainability of its farming [13]. Institutions involved in the development of local farmers in this study were grouped into four institutions, namely: input institutions, technology innovation information providers, financing institutions and marketing institutions. In general, farmers of this study met needs of fertilizers and pesticide came from the nearest farmers shop, nevertheless LEM Sejahtera Andomesinggu provided subsidized and Non Subsidized fertilizers Besulutu sub-district in cooperation with Marina Ltd, with payment model by credit system or cash money.

The most dominant provider of agricultural technology innovation information was the local extension agency. This local government agency regularly provided suggestion to farmers periodically. Members of LEM Sejahtera who collected money and gave it to those who won the lottery was the best moment for the extension to do technology dissemination, or in the form of Field School and others. In addition, government research institutes were also very instrumental in the provision of agricultural technology innovations [14]. Moreover, there were several companies or private sectors that participated in the spread of technological innovation, especially in terms of cocoa bean quality.

Table 3. The Performance of LEM Sejahtera based on the Study Site

\begin{tabular}{|c|l|l|c|l|}
\hline No. & Villages & Districts & Performance & \multicolumn{1}{c|}{ Justification } \\
\hline 1 & Epeea & Abuki & $\begin{array}{c}\text { C } \\
\text { (Not good) }\end{array}$ & $\begin{array}{l}\text { LEM Sejahtera organization already } \\
\text { had organizational goals, plans, and } \\
\text { devices which were strong enough to } \\
\text { grow up. However, it was necessary } \\
\text { to improve its performance to achieve } \\
\text { higher development }\end{array}$ \\
\hline 2 & $\begin{array}{l}\text { Andomo- } \\
\text { singgo }\end{array}$ & Besulutu & A (Good) & $\begin{array}{l}\text { LEM Sejahtera organization already } \\
\text { had an excellent capacity to maintain } \\
\text { its existence towards self-reliance and } \\
\text { sustainability. }\end{array}$ \\
\hline 3 & Waworaha & Lambuya & $\begin{array}{l}\text { C } \\
\text { (Not good) }\end{array}$ & $\begin{array}{l}\text { LEM Sejahtera organization already } \\
\text { hadganizational goals, plans, and } \\
\text { devices which were strong enough to } \\
\text { grow up. However, it was necessary } \\
\text { to improve its performance to achieve } \\
\text { higher development }\end{array}$ \\
\hline 5 & Matanggorai & Padangguni & $\begin{array}{l}\text { LEM Sejahtera organization already } \\
\text { had innovative ideas and moved to } \\
\text { look forward }\end{array}$ \\
\hline
\end{tabular}




\section{Conclusion and Policy Implications}

\subsection{Conclusions}

Local institutional directly involved in the local community of cocoa farming system was LEM Sejahtera. Providing on the supply of fertilizer and capital, Government Technical Agency in information services technology innovation, and farmers shop in the supply of fertilizer and pesticide, while in the marketing of proceeds sold to the middle of LEM Sejahtera performance prosperous village of Andomesinggu, a good category (LEM Sejahtera Organization already had an excellent capacity to maintain its existence towards self-reliance and sustainability).

\subsection{Policy Implications}

This study Policy could be as a comparison of a better management of LEM Sejahtera. Therefore, the institutional support involved can increase the knowledge and skills of farmers, facilitating access to the provision of inputs (fertilizer and pesticides), financing and others. In addition, it is recommended that farmers implement recommended technology to increase yields and improvement in the welfare of the farmers themselves.

Authors' Contribution. All the authors has been contributed significantly and equally to this paper. Rusdin has contributed to study design, Julian contributed to the outline of this paper and review, Agussalim contributed to the critical review and methodology, Dahya and Sarjoni have contributed as the valuable discussion respectively. They are the main contributors of this paper. All the authors read and agree to publish this paper.

\section{References}

1. Rosmawati, L.R. Baka., Bahari, S. A. Taridala, Saediman, J. Agri. Vet. Sci 8, 9 (2015)

2. Saediman, As. Soc. Sci 11, 5 (2015)

3. J. Witjaksono, Asmin, Agr. For. Fish 5, 5 (2016)

4. N. Schaad, I. Fromn, As. Pac. J. Sus. Agri. F. E. 6, 1 (2018)

5. L. Geo, Saediman, Pak. J. Nut 18, 5 (2019)

6. Y. Taufiq, I. Fausayana, A. Nikoyan, Hastuti, R. Basiru, J. Soc. Pol. Sci. 2, 3 (2019).

7. L. Sinaini, L. Iwe, Earth and Environmental Science (IOP Conference Series, 2020)

8. S. Raharto, Agriculture and Agriculture Science Procedia (2016)

9. Idawati, A.Fatchia., D. Ariyanto, Int. J. Inn. Tech. Exp. Eng 9, 1 (2019)

10. J. N. Nmadu, H.Sallawu, B. V. Omojeso, Eur. J. Bus. Ec. Acc. 3, 2 (2015)

11. S. O. Akintelu, L.Mele, V. O. Sobanke, M. A. Adewumni, Int. J. Agr. Inn. Tech. Glob 1, 7 (2019)

12. A. O. Matthew, As. J. Agr. Ext. Ec. Soc. 20, 3 (2017).

13. K. Silva, T. Broekel, Perceptions of Agriculture Extension Officers. (13th International Conference on Business Management, 2017)

14. M. Wessle, P.M.F.Wessel, Wag. J. L. Sci 74, 8 (2015) 